\title{
SUMMARY
}

The taxonomic history of the genus Capirona is presented. Complete synonymies, descriptions, common names, distributions and discussions are given for Capirona and its two species $\mathrm{C}$. descorticans and $\mathrm{C}$. leiophloea. The generic distribution is the Amazon valley and eastern Guianas and coincides with that of the genus Hevea. $c$. descorticans is known from the western and southeastern Amazon valley; $c$. leiophloea is reported from the eastern Guianas and the northeastern Amazon valley. The zone of contact between the two species is along the southern edge of the Amazon River and the lower drainage of the Rio Tapajoz in Parä, Brazil.

\section{Taxonomic History}

Capirona was published by Spruce based on a collection made in the area of Tara poto, Peru, in 1855. The generic name is the common name used in that region for the type species. During 1859, Spruce was traveling in the central Andian valleys of EcuaJor (Spruce, 1970) when Capirona was published in London (Spruce, 1859). Therefore he had recognized his collection as a new genus in the field and prepared the description in Peru.

A year later, Karsten (1860) presented the same genus again as Monadelphanthus based on a collection made in the 1 lanos of eastern Colombia.His generic epithet describes the basal connation of the filaments.

In volume I of Index Kewensis (Jackson, 1893) Capirona boiviniana Baillon (1880) is listed. Baillon (1880) published the new genus Pleurocoffea with a single new species, P. boiviniana. After comparing Capirona to Pleurocoffea, he mentions ' $C$. boiviniana", an obvious typographic error, which was picked up by the compliers of Index Kewens is as a new species of Capirona.

In 1912 while conducting studies of areas in which Brazil-nuts were collected near the Rio Trombetas, Brazil, Adolpho Ducke oiscovered the second species of Capirona

(*) Departamento de Biologia Vegetal. Fundação Universidade de Brasilia. Caixa Postal 153081, 70.919 Brasilia, DF, Brasil. Present address: Plant Exploration \& Taxonomy Laborat ory, Bldg. 265, BARC-East, U.S . Department of Agricul ture, Beitsvi 1 le, Mary land 20705 , USA. 
(Ducke, 1913). Unfortunately he presented the new species as a nomen nudum,

Huber in Ducke (1913). After making two additional collections of the species in 191 and 1922, he validly published it as C. huberiana (Ducke, 1922).

In 1914, Benoist collected the same species in French Guiana, but his collectiof was sterile. In 1920, M. Wachenheim, supervisor of the penal administration in Frenc Guiana, collected the species with flowers in the vicinity of the penal encampment Godebert. Benoist (1921) then used both collections as the basis of his new specie C. leiophloea which has priority over that of Ducke.

In the preparation of the Rubiaceae for the Flora of Suriname (Bremekamp, 1934a) Bremekamp (1934b) presented the necessary taxonomic changes and novelties in an extensid prior publication. Among the novelties is a new species of Capirona, C. surinamensis, He felt that it showed a strong resemblance to $C$. leiophloea, but he was unable obtain the original description of $\mathbf{C}$. leiophloea. If he had been able to see it, 1 alf confident that he would not have published his species which is, in my opinion, a taxol omic synonym of c. leiophloea.

In 1936, Standley (1936a) presented the new Peruvian genus Loretoa and its singl new species, L. peruviana. It is prophetic that Standley states, "The writer takes ne particular pride in describing this tree as a new genus ..." This is without doubt th third naming of the genus. He unfortunately had a specimen with anly a single very small foliar calyx lobe which he apparently overlooked.

In 1940, Standley published a new species of Capirona, $\boldsymbol{c}$. erythroxylon, based on collection made by Ruiz and Pavon in Peru in 1800. He was overimpressed by the foliak calyx lobe and failed to examine the flowers in detail. If he had, he would have disco vered that their aestivation is valvate and the locules contain many small, horizontally attached ovules. This species is a member of the genus Pogonopus Klotzsch.

The last species of Capirona, C. wurdacki i, was presented by Steyermark (1964) the "Botany of the Guayana Highlands." He distinguished his species fromc. decorticans; by its shorter, pink-colored corollas, more broadly infundibuliform limb of the carolla longer foliar calyx lobe, shorter style, rounded calyx lobes and somewhat shorter stipules. When $\mathbf{C}$. wurdacki $\mathbf{i}$ is compared with specimens from the entire known range of $\mathbf{C}$, decorticans, it is obvious that these "differential" characteristics occur sporadically throughout the latter species. Capirona wurdackii is a local variation which has brought these characteristics together, but it does not merit, in my opinion, formal taxonomic recognition as a species.

Capirona is presented here as comprising two species, $c$. decorticans, the type, and $C$. leioph loea.

Capirona Spruce, J. Proc. Linn. Soc., Bot. 3: 200. 1859. Type: C. decorticans Spruce, (Figs. 2, 3, 4).

Monadelphanthus Karsten, F1. columb. 1: 67, t. 33. 1860.

Type: M. floridus Karsten. 
Loretoa Standley, Field Mus. Nat, Hist., Bot.Ser. 11:221. 1936.Type: L. peruviana

Trees without raphides, glabrous or with various organs sericeous, the branches prete; stipules intrapetiolar, persistent; leaves opposite, petiolate, the petiole tete and abaxially canaliculate to weakly so, with the blade varyng from moderate to large in size, with those subtending inflorescences significantly smaller than those not subtending inflorescences; inflorescences terminal and axillary reduced thyrses, sessile or pedunculate, with the peduncle terete, with one bract subtending each branch;flowers pedicellate to subpedicellate, the pedicel terete, with 1 or 2 bracts subtending each Hower, the calyx tubular with the tube campanulate, with 5 lobes, sometimes with one lobe expanded into a large brightly colored foliar organ with a pseudopetiole and a pseudoblade, with the pseudoblade elliptic, attenuate at the base, obtuse at the apex, with 4 or 5 acrodromus primary veins, the corolla glabrous with a sericeous band inter nally at the level of stamen separation, with the aestivation dextrose contorted, with the tube plicate in bud with 15 folds, after expansion strongly infundibular, with 5 lobes, the stamens with the filaments connate near their base and separating from the corolla tube near its base, with the included anthers basifixed, narrowly oblong, the disk cup-shaped or rarely circular, the style terete, in the bottom of the disk or its cen ler, the stigria included bilobate, the 2 locules turbinate, the placenta narrowly turbinate, afixed to the center of the septum, with numerous vertically imbricate peltate ovules, the ovules elliptic or obovate; fruits capsular, turbinate, speticidal, crowned with the persistent calyx, the numerous seeds biwinged, narrowly elliptic, with the apices of the wings obtuse or irregular, the testa cells rectangular to rarely ellip tic, with the walls thick, with large circular pits in the internal wall.

\section{Dlstribution}

The genus Capirona is known to occur in the Amazon valley, the llanos of Colombia and the eastern Guianas (Fig. 1). It is a typical element of the flora of the Amazon basin and defines its 1 imits as does the genus Hevea (Ducke \& Black, 1953, 1954). Capirona decorticans is found in the western end of the Amazon valley, both north and south of the Amazon River, reaching as far as the galiery forests in the llanos of Colombia where they meet the Andes. To the north, it has been collected along the Casiquiare ca nal and once in the very uppermost reaches of the Rio orinoco heawaters. In the eastern end of the Amazon in the state of Para, Brazil, it is a found only south of the Amazon River.

The ather species of Capirona, C. leiophloea, is found in the eastern Guianas, that is Suriname and French Guiana, and extends southward into the state of Para, Brazil. It occurs both north and south of the Amazon River, and south of the river, it has been more frequently collected in the lower drainage of the Rio Tapajoz. 


\section{Taxonomic Position}

When Spruce (1857) presented the genus Capirona, he placed it in family Rubiaceae tribe Cinchoneae, and it has remained there ever since (Hooker, 1873; Bailion,1881;Schu mamm, 1889, 1891: Wernham, 1916; Standley, 1930,1936b:Bremekamp, 1934a; Steyermark, 1974 ). It has been maintained in the tribe based on its lack of raphides, contorted corolla aestivation, biloculate ovary, placenta affixed to the center of the septum, numerous vertically imbricate ovules, capsular fruit, numerous biwinged seeds, and testa cells with numerous large pits in the internal wall (Fig. 2). Even in the newest classifications (Verdcourt, 1958; Bremekamp, 1966) of the Rubiaceae, it will continue in tribe Cinchoneae.

Within Cinchoneae, Capirona has always been associated with those genera that have contorted aestivation of the corolla and one calyx lobe sometimes expanded into a large colored foliar organ, Schizocalyx Wedd. and Calycophyllum DC. (Hooker, 1873; Schumann, 1891; Wernham, 1916; Standley, 1930). It is easily distinguished from these genera by its intrapetiolar stipules, lobate calyx and connate stamens.

\section{Key to the Species of Capirona}

1. Trees with all organs glabrous; Amazonian Colombia, Ecuador, and Peru, the uppermost headwater of the Rio Orinoco, Venezuela, and Amazonias, Acre, Rondônia and southern Parä, Brazil.

\section{C. decorticans}

1. Trees with various organs densely to sparsely sericeous or glabrate; Suriname, French Guiana and Parà, Brazil.

\section{C. leiophloea}

Capirona decorticans Spruce, J. Proc. Linn. Soc., Bot. 3: 200. 1859. Type: Spruce 4202, oct 1855, Tarapoto, San Martín, Peru (holotype: K; isotypes; F, K, NY, P). (Figs. 2,3 ). Monadelphanthus floridus Karsten, Fl. columb. 1:67, t. 33.1860. Type: Karsten sn, Jiramene Caño Giramena, Llano de San Martín, Meta, Colombia (lectotype: W; isotype: LE).

Loretoa peruviana Standi., Field Mus, Nat. Hist., Bot. Ser, 11:222, 1936. Type: Klug 2022, Mar-Apr 1931, Florida, Rio Putumayo, at the mouth of the Rio Zubineta (holotype: F).

Capirona wurdacki i Steyerm., Mem. New York Bot. Gard. 10:190, 1964. Type: Wurdack \& Adderley 43383, Caño Duquiapo, Rio Casiquiare, $2 \mathrm{~km}$ above Solano, Amazonas, Venezuela (holotype: NY; isotypes: F, K, NY, P, SP, U, VEN).

Trees 7-33 m tall with a trunk diam. of 10-35(-100) cm, glabrous; stipules ovate or rarely elliptic, acute to narrowly so or rarely narrowly acuminate at the apex, $1.5-4.5(-8) \times 0.6-2.2(-2.5) \mathrm{cm}$; leaves subtending the inflarescences slightly smaller than those which do not, with the petiole $1-3 \mathrm{~cm}$ long, with the blade elliptic, cuneate or attenuate or obtuse at the base, acuminate or acute at the apex, $11-41 \times 6-24 \mathrm{~cm}, 1.5-2$ 
times longer than wide, with $(6-) 7-10(-17)$ arcuate secondary nerves on each side of the midrib, the midrib and nerves subprominent above and prominent beneath; inflorescences 7-20 $\times 10-30 \mathrm{~cm}$, with 25-150 flowers, with 1-6 flowers or rarely none with an enlarged foliar calyx lobe, with the peduncle $5-8 \mathrm{~cm}$ long, with 2-3 pairs of lateral branches $3-10 \mathrm{~cm}$ lang, with one bract subtending each branch, the bracts ovate or elliptic, acute or acuminate at the apex, $0.6-3 \times 0.4-1 \mathrm{~cm}$; flowers with the pedicel 2-7 mm long, with I or 2 bracts subtending each flower, the bracts ovate, acute at the apex,3-4.5×2-3mm, with the hypanthium turbinate, 5-6 min tall, 3-4(-5) mm in diam., the calyx with the interior sericeous, with the tube (1-) 3-5 mm tall, (5-)7-11 mm in diam. at the orifice, with the lobes very broadly acute or rarely very broadly obtuse, 0.5-3 $\times 3-5 \mathrm{~mm}$, with the foliar lobe red, with the pseudopetiole $2-4 \mathrm{~cm}$ long, with the pseudoblade $4-8.5 \times 2.5-5 \mathrm{~cm}$, the corolla tube white to pink, $20-35 \mathrm{~mm}$ long, with the lobes white to pink, ovate to broadly so, obtuse at the apex, 11-15 × 8-15 mm, the stamens separating from the corolla tube 2-3 $\mathrm{mm}$ from the base, connate for 4-6 mm from their base, with the free portion 9-14 mim long, with the anthers $6-9 \mathrm{~mm}$ long, the disk circular or cup-shaped up to $2 \mathrm{~mm}$ in diam. and depth, the style $5-8 \mathrm{~mm}$ long, the stigma lobes ovate, obtuse at the apex, $2 \times$ $0.5 \mathrm{~mm}$, the locules $3.5-4.5 \mathrm{~mm}$ tall, $1-1.5$ in diam., the placenta $3-4 \mathrm{~mm}$ tall, ca $0.5 \mathrm{~mm}$ in diam., with the sub-basally peltate ovules elliptic or obovate with the apextruncate to subtruncate, $0.6-0.8 \times 0.5 \mathrm{~mm}$; fruits $2-3.5 \mathrm{~cm}$ tall including the calyx, $0.8-1 \mathrm{~cm}$ in diam., the seeds $6-8 \times 1-2 \mathrm{~mm}$, the testa cells rectangular to elliptic, $104-301(\bar{x}=186)$ $\mu \mathrm{m}$ long, $36-75(\bar{x}=61) \mu \mathrm{m}$ wide, with the walls $6-7 \mu \mathrm{m}$ thick, with $14-34$ large pits in the internal wall, the pits $(5-) 12-32(\bar{x}=17) \mu \mathrm{m}$ in diam.

Specimens examined. Colombla. Meta: La Serranía, Liano Grande, 26 Nov 1939, Cuatrecasas 7890 (COL, F); Llano de San Martín, Triana 1791 (3264.1) (COL, F, P). Vicha da: ca $10 \mathrm{~km}$ W of Las Gaviotas along road to Puerto Gaitän, $180 \mathrm{~m}, 30 \mathrm{Dec} 1973$, Davidse * Lianos 5337 (COL, MO). VEnEzUELA. Amazonas: Cerro Sipapo (Paráque), 25 Jan 1949, Ma guire \& Politi 28613 (NY). FRENCH GUIANA. Vallée encaissée de la crique Parépou, sur des collines à environ $18 \mathrm{~km}$ de son confluent, 23 Sep 1968, oldeman 2852 (NY); pied du saut Couéki, riv. Yaroupi, affluent de l'Oyapock, 10 Apr 1970, 01 deman 3065 (NYlECUADOR. Pastaza: Tzapino, 23 May 1976, 01deman \& Arevalo 47 (US). PERU. Loreto:Varadero-Mazän, distrito Mazăn, provincia Maynas, 1 Feb 1963, Arostegui 90 (F); Varadero Amazonas, Mazän distrito Mazán, provincia Maynas, 22 Jun 1963, Arostegui 107 (F); trail from caserio of San Andrés, Rio Momon, tributary of Río Nanay, distrito lquitos, provincia Maynas, 29 Mar 1977, Rimachi 2936 (F) ; campamento del Bosque Nacional Alexander von Humboldt, distrito Callería, provincia Coronel Portillo, 23 Feb 1972, Schunke 5275 (F). San Martín: Tarapoto, Dec 1929, Williams sn (F). BRAZIL. Amazonas: Maraã, Rio Japurã, 18 Apt 1970 Albuquerque \& Lima 335 (INPA); Manaus-Caracaraí Road, km 148, 27 Sep 1973, Berg, Bisby, Steward \& Ramos P18 34 (INPA, K, MO, NY, U); south Alalau river, entre o Amazonas e Ter ritório Roraima, 26 Feb 1968, Boyan 269 (INPA); estrada Manaus-ltacoatiara, km 118 , Jul 1976, Coêlho 798 (INPA); Tabatinga, 8 Mar 1944, Ducke 1556 (F, K, NY); Cucuhy, Rio Ne gro, 26 Sep 1935, Ducke 35060 (F); Mararä, Padauiry, Rio Negro, 4 Oct 1947, Fröes 22511 
(IN, U); Reserva Florestal Ducke, Manous, 5 Jun 1964, Rodrigues b Lourei ro 5838 (INPA, RE); Səo Gabricl, Rio Negro, 8 Mar 1975, N. T. Silva 3755 (Ihí). Pará: Santarem, CuruāUna (Barreirinha), 17 oct 1964 , Campbel1 \& osmarino sn (INPA); Boa Vista,8 Mar 1933, Capu cho 550 (F); Juruty Velho, 28 May 1927, Ducke 21685 (K, P, U); Rio Verwulho,23 Apr 196l, Frós 26982 (IAt, U, UB); serraria, Serra dos Carajas, Maraba, l Apr 977 , Silva a Bahia 2990 (U8); colrada da estrada para a scrruria, Serra dos Carajüs, Maraba, 5 Apr 1977, Sil va a Bahia 3042 (UP). Acre: Colonia lias Hartins, Rio Branco, 12 Feb 1962 , Vasconcelos $\therefore$ Coêtho sn (INPA). Rondônia: Porto Velho (Rio Madeira), 9 Jan 1930, Ducke 22844 (K,P); Cachoeira de Santa Cruz, Rio Jamari, 28 wur 196\%, Pires a Martin 9950 (NY, RB, UB); 1 kr south of Riberäo, road Abuná-Guajarä-Mirin. 27 lul 1968, Prance, Forero, Wighey, Ramos Farias 6564 (F, INPA). Mato Grosso: Dardanelos, estrada Santa Elena, Rio Áripuanä, 16 Jun 1974, Cordeiro 122 (।AN, ily); Aripuana, 20 Aug 1976, Comes \& Miranda 216 (INPA), ih Mar 1977, Gomes, Miranda 0 oliveira 946 INPA); Aripuenä, proximo ao Aeroporto, 24 May 1976, Monteiro, Leite a Andrade 1043 (INPA); nargen direita do Rio Juruena, arredores do calnpo de aviaräo, 28 Jun 1977, Rosa 8 Santos 2190 (INPA, N0, NY, RB); estrada para Aripuanā, Foncanilha, Aripuaná, Rio Juruena, 30 Jun 1977, Silva 4 Maria 3234 (40, NY, UR). Common names. Colonbla: Palo de indio. ECUADor: Oyuwäe. PERU: Capirona, Capirona de altura, Capirona negro, Meta guais, Meto hudyo. BRAZlL: Mulatoiro, Pau mulato.

Disfussion, Oldeman 2852 and 3065, both sterile, have baen identified as C.decorticans on the basis of their totally glabrous condition. They have the largest stipules known in the genus, up to $8 \mathrm{~cm}$ long arid $2.5 \mathrm{~cm}$ wide. Flowering collections are reeded confirm without doubt, the presence of $\mathrm{C}$. decorticans in French Guiana.

Capirona leiophloea Benoist, Buil. Mus. Hist. Nat. (Paris) 27: 367. 1921. Types: Wachenheim 2f5, 20 bec 1920, envirens du camp de Godebert, French Guiana llectotype: P; isale ctotypes: F, K, P); Benoist 1192, 8 May 1914, Saint Jean du Maroni, Fiench Guiana (para types: P). (Figs. 2, 4).

Capirona Duckey Huber in Ducke, Bol. Hus. Paraense Hist. Not. 3:185. 1913. Nom. nud.

Capirona huberiana Ducke, Arch. Jard. Bot. Rio de Janciro 3:257. 1922. Types: Ducke 11865, 29 Jun 1912, entre os Rios Cuninä-mirime Ariramba, Rio Trombetas, Parā, Brá zi) (lectotype: RB; isolectotypes: F, P); Ducke 10468, 12 oct 1922, Bella Vista, Rio Ta pajoz, Pará, Brazi) (paratypes: RB, U); Ducke 17126, 18 Jul 1918, perto de Cachoeira Terminal, Alto Ariramba, Rio Branco - Obidos, Farä, Brazil (paratypes: F, P. RB).

Capirona surinamensis Brell., Recueil Trav. Bot. Nëerl. 3i:261. 1934. Types: Forest Bureau 1829 (tree no. 710) 9 May 1916, Bosch forest reserve, sectie o, Suriname (lectotype: U, isolectotypes: K); Forest Bureau I141 (tree no. 7/0) 8 Nov 1916 (paratype: U), 2100 (tree no. 1115 ) 18 Jul 1916 (paratype: Mo, U), 2407 (tree no. 106) 3 Nov 1916 (para type: U), 2416 (tree no. 710) 6 Sep 1916 (paratype: U), 4246 (tree no, 106) 13 Feb igig (paratype: U), 4397 (cree no. 106) 3 Nov 1919 (paratypes: K, NY, RB, U), Bosch forest reservo, sectie 0 , Suriname. 
Trees 11-32 m tall with a trunk diam. of $20-45 \mathrm{~cm}$, the branches sparsely sericeous tien very young and then glabrate to glabrous; stipules ovate or elliptic to narrowly so, acute at the apex, $2.5-5 \times 1-1.6 \mathrm{~cm}$, with the abaxial surface sparsely sericeous, with the adaxial surface with a few appressed hairs; leaves of vegetative branches with the periole 2-2.5 cm long, sparsely sericeous, with the blade elliptic or obovate to narrowly so, obtuse or cuneate at the base, broadly acute or acuminate or obtuse at the apex,22$40 \times 8.22 \mathrm{~cm}, 1.5-3.3$ times longer than wide, glabrous or glabrate above and sparsely sericeous or with a few appressed hairs below, with (10-)12-24 arcuate secondary nerves on each side of the midrib, the midrib and nerves plane above and prominent beneath, the leaves of fertile branches with the petiole terete, $0.5-1.5 \mathrm{~cm}$ long, sparselysericeous, with the blade narrowly to broadly elliptic, obtuse or rarely cordate at the base, broadly acute or obtuse at the apex, $5-15 \times 2-8.5 \mathrm{~cm}, 1.2-2$ times longer than wide, glabro us or glabrate above and sparsely sericeous beneath, with $5-9$ arcuate secondary nerves on each side of the midrib, the midrib and nerves plane and subprominent to prominent beneath; inflorescences $9-25 \times 12-30 \mathrm{~cm}$, with $(10-) 25-100$ flowers, with 1 or 2 flowers or rarely none with an enlarged foliar calyx lobe, with the peduncle $6-8 \mathrm{~cm} 10 \mathrm{ng}$, sparsely sericeous, with $2-5$ pairs of lateral branches $2.5-15 \mathrm{~cm}$ long, sparsely sericeous, with the one bract subtending each branch ovate, acute at the apex, $1.2-2 \times 0.5-0.8 \mathrm{~cm}$, with the abaxial surface glabrate to sparsely sericeous, with the adaxial surface glabrous to glabrate; flowers with the pedicel $2-7 \mathrm{~mm}$ long, glabrate to sparsely sericeous, with one bract subtending each flower, the bract broadly ovate, acute at the apex, $4.5-$ $6.5 \times 3-5 \mathrm{~mm}$, with the abaxial surface glabrate to sparsely sericeous, with the adaxial surface glabrous to glabrate, with the hypanthium fusiform, 4-7 mm tall, 3-4 mm indiam., sericeous, the calyx with the exterior sericeous to weakly so, with the interior densely sericeous, with the tube 4-6 mm tali, 7-10 $\mathrm{mm}$ in diam. at the orifice, with the lobes very broadly acute or very broadiy obtuse, $1-2 \times(3-) 4-7 \mathrm{~mm}$, with the foliar lobe with the pseudopetiole $1-4.5 \mathrm{~cm}$ long, sparsely sericeous to glabrate, with the pseudoblade 2.5-7 × 1-4 cm, glabrate above, sparsely sericeous below, the corolla tube $25-30 \mathrm{~mm} l o n g$, with the lobes circular, obtuse at the apex, $10-13 \times 10-13 \mathrm{~mm}$, the stamens separating from the corolla tube $3 \mathrm{~mm}$ from the base, connate for $5-6 \mathrm{~mm}$ from their base, with the free portion of the filaments $10-12 \mathrm{~mm}$ long, with the anthers ca $8 \mathrm{~mm}$ long, the disk cup-shaped, $1.5 \mathrm{~mm}$ in diam. and depth, the style $9 \mathrm{~mm}$ long, the stigma lobes eliiptic, obtuse at the apex, $2 \times 1 \mathrm{~mm}$, the locules 5-6 mm tall, 1-1.5 mm in diam., the placenta ca $4 \mathrm{~mm}$ tall, ca $0.5 \mathrm{~mm}$ in diam., with the centrally peltate ovules elliptic, 0.6-0.9 $x$ $0.4 \mathrm{~mm}$; fruits $2.5-3.5 \mathrm{~cm}$ tall including the calyx, $1-1.3 \mathrm{~cm}$ in diam., glabrate or spar sely sericeous, the seeds $6-8 \times 1.5-2 \mathrm{~mm}$, the testa cells rectangular, $156-333(\bar{x}=232)$

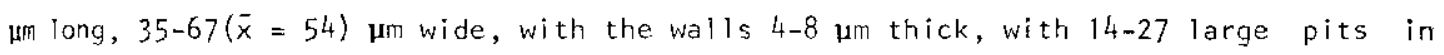
the internal wall, the pits $12-33(\bar{x}=21)$ um in diam.

Specimens examined. SURINAME. Hoogbosarboretum Kamp 8 Mapanegebied, 3 Sep 1970, Elburg \& Roberts 12634 (U); Bosch forest reserve, sectie 0, Forest Bureau 172 , Dec 1942 (K, NY, U), 172a, May 1945 (COL, K, MO, NY, SP, U); from confluence of Lucie and 0ost 
Rivers to $5 \mathrm{~km}$ east, alt. 275-325 m, $8 \mathrm{Sep} \mathrm{1963,} \mathrm{Imin,} \mathrm{Prance,} \mathrm{Soderstrom} \mathrm{\&} \mathrm{Holmgren}$ 55528 (COL, F, K, MO, NY, SP, U); Jodensavanne-Mapane kreek area (Suriname R.), 2 Apr 1953, Lindeman 3681 (U), 2 Mar 1961, Schulz 8583 (F, U); Brownsberg Nature Park near main park headquarters, $90 \mathrm{~km} S$ of Paramaribo, Mazaroni Plateau, 26 Sep 1976, Morì \& Bolten 8413 (K, MO, NY, U) ; Brownsberg, 24 Jun 1970, Tawjoeran 12851 (U). FRENCH GUIANA. Route de Cayenne, $\mathrm{km} \mathrm{7,980,} 23$ Mar 1956, collector unknown 7408 (P, U). BRAZIL. Parä: Igarapé do Lima, planalto de Santarem, 25 Jun 1954, Fröes 30960 (IAN, K, NY, U); Itaitu ba, Rio Tapajoz, 4 Feb 1952, Pires 4054 (IAN); estrada entre Plião e Repartimento, re gião do Jari, 6 May 1970, N. T. Silva 3113 (IAN); estrada do Munguba km 10, regiäo do Jari, 22 oct 1970, N. T. Silva 3388 (IAN). Common names. SURINAME: Akatombe, Akatomno, Akegoemio, Akepenio, Akhorok, Kalidan, Kalidan, Kantasie hoedoe, Moentene, Moentenehe, Toelalahoedoe. FRENCH GUIANA: Bouchi Banda.

Discussion. The pubescence density of C. leiophloea forms a cline from north to south. The most densely sericeous members of the species are found in the northern part of its range, Suriname and French Guiana. The most sparsely sericeous forms are found at the southern limits of its range, south of the Amazon River along the lower drainage of the Rio Tapajoz. Those collections from north of the Amazon River and south of the Guianas exhibit an intermediate pubescence density. The area in which the sparsest pubescence is found, is also the zone of contact between $\mathrm{C}$. leiophloea and $\mathrm{C}$. decorticans, Perhaps the sparser pubescence of $\boldsymbol{C}$. leiophloea in this region indicates a possible exchange of genes sometime in the past. Our present knowledge is insufficient to evaluate this situation. Intensive collecting in the zone of contact and hybridization studies are needed to clarify this situation.

\section{Excluded Species}

Capirona boiviniana Baillon, Bul1. Mens. Soc. Linn. Paris 1:270. 1880, is a typo graphic error for Pleurocoffea boiviniana Baillon.

Baillon (1880) presented the new genus Pleurocoffea with a single species, P. boi viniana, and validated both jointly. He compared his new genus to Platycarpum Humb. \& Bonpl., Capirona, Coffea L., Posoqueria Aubl. and Canthium Lam. Pleufocoffea boiviniana was transferred to the genus Coffea and was remained there (de Wildeman, 194$\}$; Chevalier, 1947). In comparing his genus to Coffea, Bailion (1880) mentioned 'C. boiviniana'. Un doubtedly "c" was substituted for "p" by mistake. The first genus beginning with "c" to appear before 'C. boiviniana"' was Capirona, so in volume I of Index Kewensis (Jack son, 1893) boiviniana was cited as a new species of both Pleurocoffea and Capirona.

Capirona erythroxylon standley, Publ. Field Mus. Nat. Hist., Bot. Ser.

$22: 49$. 1940. = Pogonopus erythroxylon (Standl.) Kirkbride, comb. nov. Type: Ruiz \& Pavon sn, Peru (holotype: MA (specimen with autographic label, "Pentandria Monogynia, Genus novum [crossed out.]. Vulgo palo Colorado. F. H. D. 139. L 495. Año de 1800. 19a Sp. (Macro cnemum)."); isotype: MA (duplicate specimen without autographic label). 
Standley was apparently overimpressed with the calyx structure of c. erythroxylon. he had looked at the specimens in more detail, he would have discovered that they have glvate aestivation and many small, horizontal ovules in each locule. The only genus onbining thesecharacterswith one calyx lobe sometimes expanded into a large colored Wliar organ, is Pogonopus klotzsch. The genus was reported to have two species, $P$. Peciosus (Jacq.) Schum. and P. tubulosus (DC.) Schum. (Oersted, 1852; Schumann, 1889, 891; Standley, 1938; Sandwith, 1949; Steyermark, 1974; Dwyer, 1980), which differ mark fidy from $P$. erythroxylon by persistent stipules, generally smaller leaves and slightly ionger, slenderer corollas.

\section{ẂRNOWLEDGMENTS}

I thank the following institutions for loaning or allowing access to collections For this study: COL, F, IAN, INPA, LE, MA, NY, P, RB, SP, U, and W, and I thank K for fupplying a list of their collections and photographs of their types.

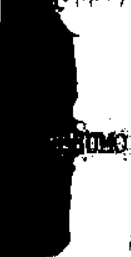

Apresenta-se un histōrico taxonômico do gênero Capirona, sinonimia completa, descriçoes, nomes vulgares e discussöes refierentes, tanto para o genero, cumo para as duas upecios, C. decorticans e C. leiophloea. A distribuiçäo geografica do gênero abrange as bacias dos Rios Amazonas e Solimões, e caincide cam a distribuiçäo do gênero Hevea. Capirona decorticans $\bar{e}$ conhecida do oestie e do sudeste do Amazonas e c. leiophloea do loste das Guianas e do nordeste do Amazonas. A zona de contacto entre as duas espēcies i a beira sul do Rio Amazonas e a parte baixa da bacia do Rio Tapajös no Estado do Parā, Brasil. 


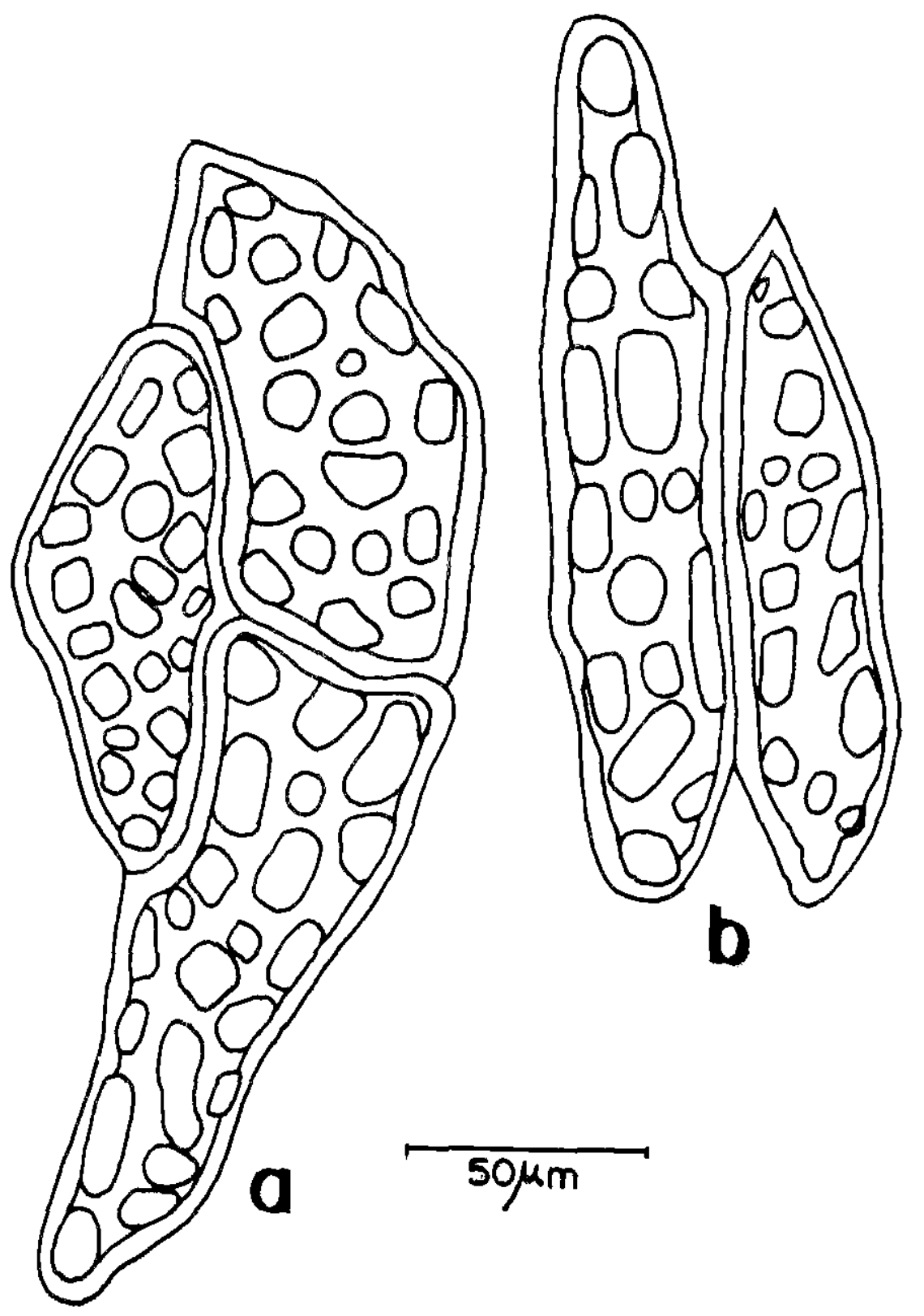

FIG. 1. Testa cel1s of: a) Capirona decorticans (Prance et al. 6564 INPA) and b) c. leiophloea (Irwin et a1. 55528 NY). 


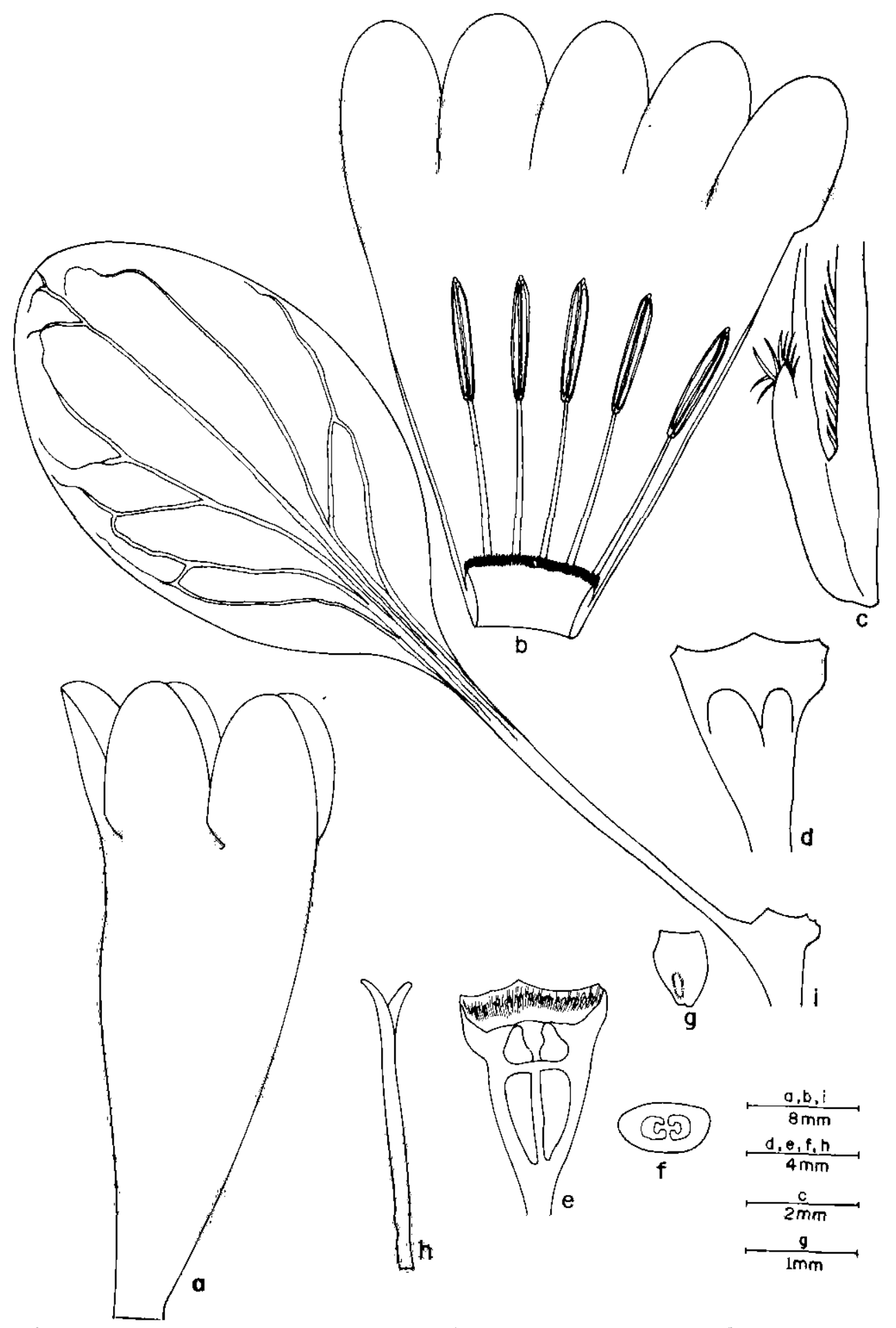

PIG. 2. Floral analysis of Capirona decorticans: a) the corolla, b) the corolla spread open, c) section of the base of the corolla with a filament, d) the hypanthium, e) transverse section of the hypanthium and locules with the placentas and ovules removed, f) cross-section of the hypanthium and locules with the pla centas and ovules removed, g) an ovule, h) the style and stigma, and i) the hypanthium with one calyx lobe a large foliar organ (Boyan 269 INPA). 

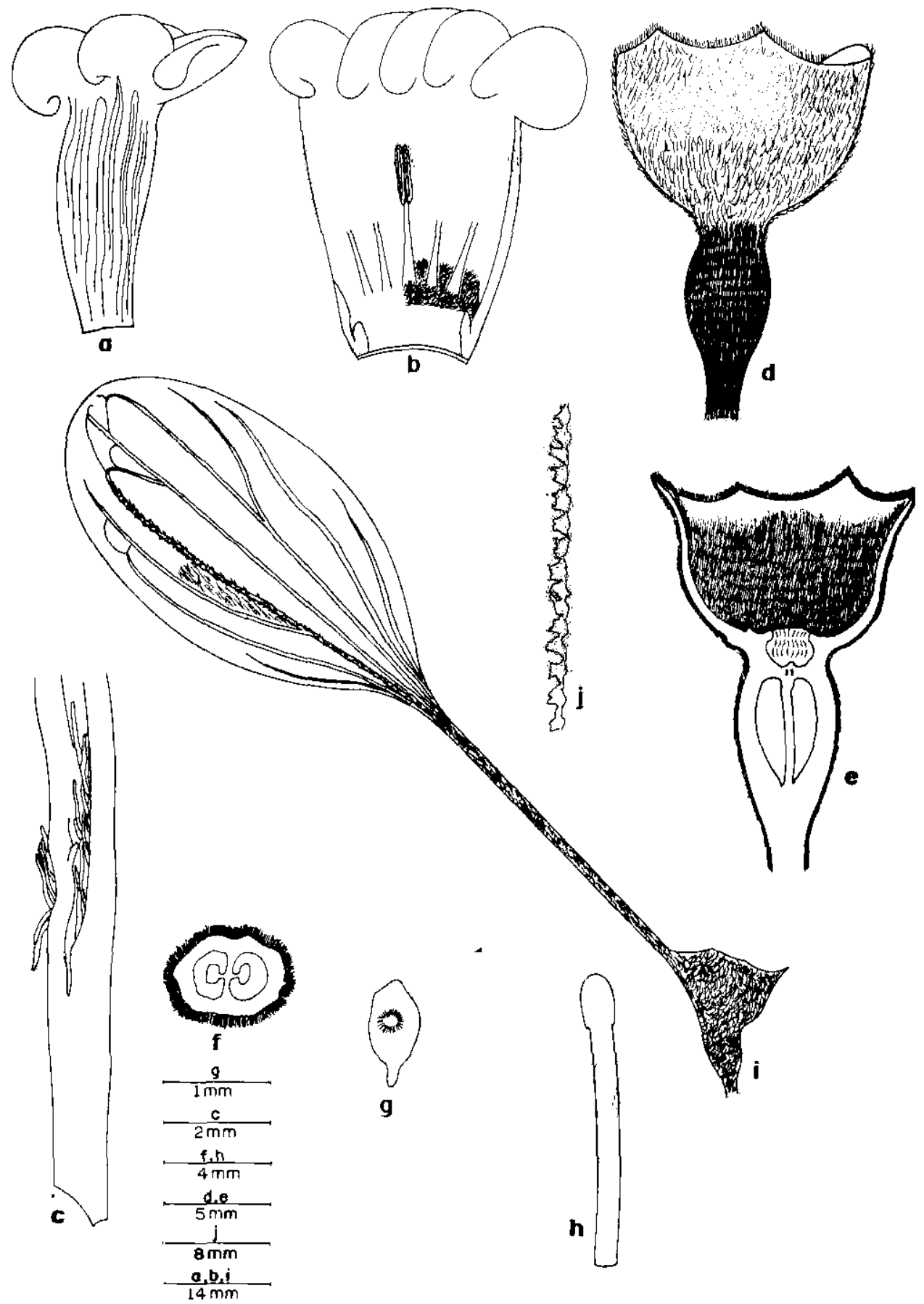

EIG: 3. Floral analysis of Capirona leiophloea: a) the corolla, b) the corolla spread open, c) section of the base of the corolla with a filament, d). the hypanthium, e) transverse section of hypanthium and locules with the placentas and ovules removed, f) cross-section of the hypanthium with the placentas and ovules removed, g) an ovule, h) the style and stigma, i) the hypanthium with one calyx lobe a large foliar organ, and $j$ ) cross-section of the corolla wall showing the plicate folds, exterior to the left and interior to the right (Silva 3113 IAN). 


\section{Ré eréncias bibliogräficas}

Prillon, M. H. - 1880. Sur le Pleurocoffea. Bul1, Mens. Soc. Linn, Paris, 1 (34): 270 .

1881. The Natural History of Plants. London. Love11 Reeve \& Co., v. 7.

Bnnoist, M. R. - 1921. Liste de plantes rëcoltées par M. Wachenhein en Guyane Française. Bull. Mus. Hist. Nat., Paris, 27: 366-368.

Bremekamp, C. E. B. - 1934a. Rubiaceae. In: Pulle, A. - Flora of Suriname, 4(1): 113298.

- 1934b. Notes on the Rubiaceae of Surinam, Rec. Trav. Bot. Néerl., Soc.

Bot . Nér1., $31(1-2): 248-308$.

- 1966. Remarks on the position, the delimitation and the subdivision of the Rubiaceae. Acta Bot. Nëerl., 15: 1-33.

Chalier, A. - 1947. Les Cafëiers du Globe. fascicule IJ. P. Paris, Lechevalier.

Ducke, A. - 1913. Exploraçöes científicas no Estado do Parä, Bol. Mus. Goeldi (Mus. Paraense) Hist. Nat. Ethnografia, 3: 100-199.

--- - 1922. Plantes nouvellas ou peu connues de la région amazonienne (II e Partie). Arch. Jard. Bot. Rio de Janeiro, 3: 3-282.

Ducke, A.\& B1ack, G.A.- 1953. Phytogeographical notes on the Brazilian Amazon.Anais Acad. Bras. Cièn., 25: 1-46.

- 1954. Notas sobre a fitogeografia da Amazónia brasileira. Bol. Tec. Inst.Agron. Norte, 29:1-62.

Dwyer, J. D. - 1980. 65. Pogonopus. In: Woodson fr., R. E. \& Schery, R. W. - Flora of Panama. Part IX, Family 179. Rubiaceae - Part II. Ann. Míssouri Bot. Gard., 62 (2): $329-333$

Hooker, J. D. - 1873. Rubiaceae. In: Bentham, G. \& Hooker, J. D. - Genera plantarum 2(1): 7-1.52, London. Love11 Reeve \& Co.

pekson, B. D. - 1893. Index Kew. Oxford, Claredon. v. 1.

arsted, A, S. - 1852. Centralamerikas Rubiaceer, Vidensk. Meddel. Dansk Nathurist. Foren. Kjobenhavn, $1852(2-4): 23-61$.

Schumann, C. - 1889. Rubiaceae. In: von Martins, C. F. P. ed. Flora brasiliensis,6(6): $1-466$.

Schumann, C. - 1981. Rubiaceae. In: Engler, A. \& Prantl, K. eds., Die natürlichen Pflanzenfarailien, 4(4): 1-156.

Spruce, R. - 1859. On five new plants from Eastern Peru. J. Proc. Linn. Soc., Bot., 3: $191-204$.

-- 1970. Notes of a botanist on the Amazon \& Andes. Reprint of 1908. New York, Johnson Reprint Corp.

Standley, P. C. - 1930. The Rubiaceae of Colombia. Publ. Field. Columian Mus., Bot. Ser., $7: 3-175$.

- 1936a. Studies of American Plants. - V1. Field Mus. Nat. Hist., Bot. Ser., 11 (5): $145-276$. 
- 1936b. Rubiaceae. In: MacBride, J. F. ed. - Flora of Peru. Field. Mus. Nat. Hist., Bot. Ser., 13: 3-26I.

- 1938. Pogonopus Klotzsch. In: Flora of Costa Rica (part IV). Publ. Field Mus. Nat. Hist., Bot. Ser., 18(4):1339-1340.

--- - 1940. Studies of Amerifan Plants - IX. Pub1. Field. Mus. Nat. Hist., Bot. Ser. 22 (1): $3-62$.

Steyermark, J. A. - 1964. Rubiaceae. In: B. Maguirre \& colaboradores, Botany of the Guyana Highland - Part V. Mem. New York Bot. Gard., 10 (5): 186-278.

--- - 1974. Rubiaceae, primeira parte. In: Lasser, T. - Flora de Venezuela, 10 (1) $1-593$.

Verdecourt, B. - 1958. Remarks on the classification of the Rubiaceae.Bull. Jard. Bot. Etat. Bruxe11es, 28 (3): 209-281.

Wernham, H. F. - 1916. Tropical American Rubiaceae. - VII. - The Genera. J. Bot., 54: $322-334$.

Wildeman, E. de - I941. Etudes sur le genre Coffea L. Bruxelles. Acadërie Royale de Eelgique.

(Aceito para publicação em 01.11.84) 